\title{
CASSIODORUS, INSTITVTIONES 1.28.3 AND LACTANTIUS, DIVINAE INSTITVTIONES 3.28.22*
}

\begin{abstract}
This note identifies the source of a brief quotation in Cassiodorus, Institutiones 1.28.3 as a passage of Lactantius, Diuinae Institutiones 3.28.22. It argues that Cassiodorus possibly intended to draw an implicit comparison between himself and Lactantius.
\end{abstract}

Keywords: Cassiodorus, Institutiones; Lactantius, Diuinae Institutiones; Origen; Abbé Morel

In Inst. 1.28, Cassiodorus writes that the study of letters-both sacred and secularshould not be neglected, since they enable a better understanding of the Scriptures. However, readers have to keep in mind that letters alone cannot lead to the truth, as is shown by many ancient philosophers, who never reached the source of wisdom because they did not possess the true light. After these reflections, Cassiodorus writes: quoniam, sicut a quodam dictum est, numquam potest plenissime inuestigari, quod non per uiam suam quaeritur ('as someone has said, whatever is not sought for in its own way cannot be completely tracked down'). ${ }^{1}$

This quotation is briefly mentioned by Schirren in his book about Jordanes and Cassiodorus. ${ }^{2}$ He believed that Jordanes did not state openly that he had taken the beginning of his preface to the Getica from Rufinus' preface to the translation of Origen's Explanatio super epistulam Pauli ad Romanos because of the dubious orthodoxy of the Alexandrian scholar. ${ }^{3}$ According to Schirren, 'idem Cassiodorio placuisse puto, in lib. de inst. div. lit. c. $28,{ }^{4}$ This attempt to trace the quotation back to Origen was not followed by the editor and by the translators of Cassiodorus' Institutiones, who did not try to find the passage's source. Schirren was right in looking for a Christian author, but he missed the most obvious candidate, another writer who authored a treatise entitled Institutiones, namely Lactantius. Chapter 28 of Book 3 of his Diuinae Institutiones is about the ancient philosophers who were not wise because they missed God in their quest for the truth. After making his point by mentioning quite

* This note was written at the Friedrich-Meinecke-Institut during the term of a direct exchange programme. I would like to thank the Freie Universität Berlin for its very generous support, which made my research in Germany possible. I am most grateful to $C Q$ 's editor Bruce Gibson and to the anonymous reader for their helpful comments.

${ }^{1}$ Cassiod. Inst. 1.28.3 (R.A.B. Mynors [ed.], Cassiodori senatoris Institutiones [Oxford, 1937], 70). The English translation is taken from J.W. Halporn (transl.), Cassiodorus. Institutions of Divine and Secular Learning and On the Soul (Liverpool, 2004), 160.

${ }^{2}$ C. Schirren, De ratione quae inter Iordanem et Cassiodorium intercedat commentatio (Tartu, 1858), 23.

3 See Rufin. Praef. ad Orig. In Rom. and Iord. Get. 1-3.

${ }^{4}$ For a more recent attempt to identify the quotation's source, see G. Jenal, Italia ascetica atque monastica: Das Asketen- und Mönchtum in Italien von den Anfängen bis zur Zeit der Langobarden (ca. 150/250-604) (Stuttgart, 1995), 654 n. 65, who supposes that the passage comes from Augustine.

(C) The Author(s), 2021. Published by Cambridge University Press on behalf of The Classical Association. This is an Open Access article, distributed under the terms of the Creative Commons Attribution-NonCommercial-

NoDerivatives licence (http://creativecommons.org/licenses/by-nc-nd/4.0/), which permits non-commercial re-use, distribution, and reproduction in any medium, provided the original work is unaltered and is properly cited. The written permission of Cambridge University Press must be obtained for commercial re-use or in order to create a derivative work. 
a few examples, Lactantius concludes by writing that numquam enim potest inuestigari quod non per uiam suam quaeritur (Diu. Inst. 3.28.22).

As far as I know, Cassiodorus' passage has been correctly attributed to Lactantius only by Abbé Morel in $1766,{ }^{5}$ yet his observation has been ignored not only by Schirren but also by subsequent editors and translators of the Institutiones. Moreover, Morel was not interested in the context of the sentence but in the quotation itself, so he did not look into the purpose of this reference to Lactantius. Cassiodorus transcribed the sentence almost verbatim, adding only the adverb plenissime, and placed it shortly before the only reference to Lactantius in the Institutiones, which occurs at the beginning of the following paragraph, where he quotes Augustine's De doctrina Christiana 2.40 .61 (nonne aspicimus quanto auro et argento et ueste suffarcinatus exierit de Aegypto Cyprianus, et doctor suauissimus et martyr beatissimus? quanto Lactantius, quanto Victorinus, Optatus, Hilarius?) in order to indicate that quite a few Christian writers who had a profound knowledge of both secular authors and divine law were able to reach true wisdom.

The name of Lactantius is introduced by a passage of his Diuinae Institutiones, so it is possible that Cassiodorus intended to draw a comparison between himself and his illustrious predecessor. ${ }^{6}$ Thanks to his deep secular learning and his Christian faith, Lactantius managed to understand the essence of true religion and to convey his wisdom to others through his books. Cassiodorus, whose knowledge of secular letters is attested shortly afterwards by a Virgilian quotation, ${ }^{7}$ and whose faith was well known, was likewise able to help-through his works-those who struggled in order to catch a glimpse of the mysteries of the divine wisdom. By quoting from Diu. Inst. 3.28.22, Cassiodorus may have indicated that both he and Lactantius, unlike ancient philosophers, had managed to come to the true 'source both of knowledge of this world and of the salvation of the soul'. ${ }^{8}$

Scuola Normale Superiore di Pisa

MARCO CRISTINI marco.cristini@sns.it doi:10.1017/S0009838821000379

\footnotetext{
5 J.B. Morel, Éléments de critique, ou recherches des différentes causes de l'altération des textes latins, avec les moyens d'en rendre la lecture plus facile (Paris, 1766), 59 (reissued in M. Quantin, Dictionnaire raisonné de diplomatique chrétienne, contenant les notions nécessaires pour l'intelligence des anciens monuments manuscrits, avec un grand nombre de fac-simile [Paris, 1846], 997). However, Morel indicated 'divinarum Instit. Lib. 9. cap. 28. lin. ult.' as the source, whereas the quotation comes from Book 3.

${ }^{6}$ According to E.K. Rand, 'The New Cassiodorus', Speculum 13 (1938), 433-47, at 435, 'Cassiodorus evidently had in mind the title of Lactantius's work, Diuinae Institutiones'. However, P. Stoppacci, 'Liste di autori nell'opera manualistica di Cassiodoro: le Institutiones tra la scuola antica e la biblioteca di Vivarium', Filologia mediolatina 24 (2017), 1-47, at 24-5 believes that Cassiodorus' main model was Iunillus and his Instituta regularia diuinae legis.

${ }^{7}$ Cassiod. Inst. 1.28 .5 and Verg. G. 2.484-5.

${ }^{8}$ Cassiod. Inst. praef. 1 (transl. Halporn [n. 1], 105): unde et salus animae et saecularis eruditio prouenire monstratur.
} 